\title{
Investigation of the postruminal methionine requirement of growing lambs by using the indicator amino acid oxidation technique
}

\author{
Gao Wei, Liu Chen, Gao Xinmei, Zhang Fan, Chen Daofu, Liu Chenli* \\ College of Animal Science \& Technology, Shihezi University, Shihezi City, 832003, PR China
}

\section{A R T I C L E I N F O}

\section{Keywords:}

Methionine

Requirement

IAAO technique

Stable isotope

Lamb

\begin{abstract}
A B S T R A C T
Methionine was demonstrated to be the most limiting amino acid for growing sheep when microbial protein is the predominant source of absorbable AA, but its specific requirement was not well quantified. The indicator amino acid oxidation (IAAO) method is based on the concept that when the most limiting amino acid (LAA) is deficient for protein synthesis, then all other AAs will be oxidized. With increasing intakes of the LAA, IAAO will decrease until the requirement for the LAA is met, and there is no further change in the indicator oxidation afterwards. Therefore, the catabolism of ${ }^{13} \mathrm{C}$-Phe was used to indicate the effects of varying duodenal infusing levels of Met on the oxidation rate by 4-month-old Kazakh lambs $(30.8 \pm 0.4 \mathrm{~kg} \mathrm{BW})$. After a 6 -d adaptation period, the IAAO test was conducted on $\mathrm{d}$ 7. Each lamb received a priming dose of $0.67 \mathrm{mg} / \mathrm{kg}$ BW of ${ }^{13} \mathrm{C}$-Phe injected via the jugular vein, together with $0.18 \mathrm{mg} / \mathrm{kg}$ BW of $\mathrm{NaH}^{13} \mathrm{CO}_{3}$ at time 0 . Then, constant infusions $\left[1.33 \mathrm{mg}{ }^{13} \mathrm{C}-\mathrm{Phe} /(\mathrm{kg} \mathrm{h})^{-1}\right]$ were started. Breath samples were collected prior to and half-hourly between 90 and $210 \mathrm{~min}$ after the start of the ${ }^{13} \mathrm{C}$ Phe infusions. An estimate of the mean Met requirement was determined by a breakpoint analysis of the rate of ${ }^{13} \mathrm{CO}_{2}$ released by ${ }^{13} \mathrm{C}$-Phe oxidation, with a 2-phase linear regression model. The oxidation rate of ${ }^{13} \mathrm{C}$-Phe decreased $(\mathrm{P}<0.001)$ with increasing amounts of methionine infused in a dose-dependent fashion up to $1.65 \mathrm{~g} /$ day, and it was not different from 1.65 to $2.15 \mathrm{~g} / \mathrm{day}$ $(\mathrm{P}>0.05)$. The mean Met requirement was estimated to be $1.28 \pm 0.11 \mathrm{~g} /$ day of supplementation. The total postruminal minimum requirement of Met would be $2.02 \mathrm{~g} /$ day when the basal passage of Met ( $0.74 \mathrm{~g} /$ day) was summed.
\end{abstract}

\section{Introduction}

It is well documented that methionine (Met) and cysteine (Cys) are the primary limiting amino acids for wool production in sheep (Liu and Masters, 2003). It was also demonstrated that wool production and live-weight gain can be improved by supplementing sheep with Met (Williams et al., 1988; Reis et al., 1990; Mata et al., 1995). However, the specific requirement of Met for growing ruminants remains elusive (MacRae et al., 1997). Traditionally, amino acid (AA) requirements for growing animals were quantitatively estimated by feeding diets of varied AA contents and measuring the growth rate, nitrogen (N) retention, feed efficiency and plasma AA concentrations. For ruminants, pregastric metabolism necessitates the quantification of post-ruminal

\footnotetext{
Abbreviations: AA, amino acids; N, nitrogen; IAAO, indicator AA oxidation; DMI, dry matter intake; NDF, neutral detergent fiber; ADF, acid detergent fiber; BW, body weight; TMR, totally mixed ration; APE, atom percent excess

* Corresponding author.

E-mail address: liuchenli@shzu.edu.cn (L. Chenli).
} 
Table 1

Composition and nutrient levels of three total mixed rations (DM basis).

\begin{tabular}{|c|c|}
\hline Ingredients, $\mathrm{g} / \mathrm{kg}$ of diet & Composition \\
\hline Ground corn & 8.4 \\
\hline Commercial concentrate supplement ${ }^{\mathrm{a}}$ & 35.4 \\
\hline Alfalfa meal & 14.4 \\
\hline Wheat straw & 28.2 \\
\hline Cottonseed hull & 13.6 \\
\hline Total & 100.0 \\
\hline Digestible energy, $\mathrm{DE}^{\mathrm{b}}(\mathrm{MJ} / \mathrm{kg})$ & 11.72 \\
\hline Total digestible nutrients, $\mathrm{TDN}^{\mathrm{b}}(\%)$ & 64.94 \\
\hline Crude protein, $\mathrm{CP}(\%)$ & 13.00 \\
\hline Neutral detergent fiber, NDF (\%) & 47.74 \\
\hline Acid detergent fiber, ADF (\%) & 24.64 \\
\hline Calcium & 0.55 \\
\hline Phosphorus & 0.34 \\
\hline Concentrate forage ratio & $59: 41$ \\
\hline Arginine & 3.73 \\
\hline Histidine & 2.78 \\
\hline Isoleucine & 2.87 \\
\hline Leucine & 6.99 \\
\hline Lysine & 3.49 \\
\hline Methionine & 1.41 \\
\hline Phenylalanine & 3.83 \\
\hline Threonine & 3.02 \\
\hline Tryptophan & 0.50 \\
\hline Valine & 3.40 \\
\hline TEAA $^{\mathrm{c}}$ & 32.02 \\
\hline Alanine & 4.79 \\
\hline Aspartic acid & 6.72 \\
\hline Cystine & 1.76 \\
\hline Glutamic acid & 12.92 \\
\hline Glycine & 3.06 \\
\hline Proline & 4.32 \\
\hline Serine & 3.19 \\
\hline Tyrosine & 2.01 \\
\hline TNEAA $^{\mathrm{c}}$ & 38.78 \\
\hline
\end{tabular}

\footnotetext{
a The commercial concentrate supplement provided the following per kg of diets: ground corn, $644.6 \mathrm{~g}$; sprayed corn bran, $42.4 \mathrm{~g}$; DDGS, $60.0 \mathrm{~g}$; soybean meal, $176.9 \mathrm{~g}$; cottonseed protein, $50.0 \mathrm{~g}$; calcium hydrophosphate, $6.2 \mathrm{~g}$; fine limestone, $11.8 \mathrm{~g}$; salt, $5.1 \mathrm{~g}$; vitamin premix, $1.0 \mathrm{~g}$; and trace element premix, $2.0 \mathrm{~g}$.

${ }^{\mathrm{b}}$ DE and TDN were calculated values, while the others were measured values.

c TEAA stands for total essential amino acids and TNEAA stands for total nonessential amino acids.
}

requirement of amino acids. Unfortunately, due to the lack of data on the AA composition of endogenous $\mathrm{N}$ in sheep, as well as the utilization efficiencies of individual amino acids for various productive purposes, it is very difficult to adapt and use the conventional metabolizable protein requirement system for amino acids (Liu and Masters, 2000). Therefore, an alternative approach is necessary to directly estimate the requirement of individual amino acid for sheep.

The indicator AA oxidation (IAAO) technique, initially developed in pigs (Kim and Bayley, 1983; Ball and Bayley, 1984), has been widely used to determine the AA requirements in pigs (Bertolo et al., 2005; Moehn et al., 2008) and humans (Pencharz and Ball, 2003; Elango et al., 2008). The IAAO allows measurements to be made after a short adaptation period of $2 \mathrm{~d}$ for pigs (Moehn et al., 2004) and $2 \mathrm{~h}$ for humans (Bross et al., 1998) so that sufficient levels of AA intake can be tested within short experiment durations without changing their physiological state. Therefore, the objectives of this experiment were to determine the supplemental postruminal need for Met by growing lambs and to estimate total postruminal Met minimum requirement of individual lambs under practical feeding conditions.

\section{Materials and methods}

\subsection{Animals and diets}

All of the procedures used in this study were approved by the Animal Care and Use Committee of Shihezi University. The procedures and diets used in this study were described in detail by Gao et al. (2016). In brief, three Kazakh lambs (30.8 $\pm 0.4 \mathrm{~kg}$ initial BW at 4-months), each fitted with a permanent cannula in the proximal duodenum, were maintained in individual crates $\left(1.4 \times 0.6 \mathrm{~m}^{2}\right)$ at a constant room temperature of $20{ }^{\circ} \mathrm{C}$ under continuous lighting. The lambs were fed twice daily (08:00 and 20:00) with equal parts of the diet in 12-h intervals in order to maintain a relatively stable rumen environment. The feed composition and 
Table 2

The profiles of duodenal infusions of mixed AA solutions ( $\mathrm{g} /$ day).

\begin{tabular}{|c|c|c|c|}
\hline Item & Metabolizable AA requirements ${ }^{\mathrm{a}}$ & Metabolizable AA supplies ${ }^{\text {b }}$ & Profiles of duodenal infusion of AA solutions ${ }^{c}$ \\
\hline Arginine & 7.96 & 2.28 & 5.68 \\
\hline Histidine & 2.28 & 3.67 & - \\
\hline Isoleucine & 3.73 & 2.01 & 1.72 \\
\hline Leucine & 7.88 & 5.03 & 2.85 \\
\hline Lysine & 6.40 & 3.46 & 2.94 \\
\hline Methionine $^{\mathrm{d}}$ & 1.65 & 0.74 & $0.17-2.15$ \\
\hline Phenylalanine & 4.01 & 2.47 & 1.54 \\
\hline Threonine & 5.54 & 3.78 & 1.76 \\
\hline Valine & 4.83 & 2.94 & 1.89 \\
\hline Alanine & 7.48 & 3.76 & 3.72 \\
\hline Aspartic acid & 8.30 & 5.24 & 3.06 \\
\hline Cysteine & 2.29 & 0.16 & 2.13 \\
\hline Glutamic acid & 13.30 & 9.32 & 3.98 \\
\hline Glycine & 9.24 & 2.84 & 6.4 \\
\hline Proline & 6.41 & 2.58 & 3.83 \\
\hline Serine & 5.15 & 2.28 & 2.87 \\
\hline Tyrosine & 3.47 & 2.01 & 1.46 \\
\hline
\end{tabular}

${ }^{a}$ Metabolizable AA requirements were calculated using the net protein requirements (18) for $200 \mathrm{~g} / \mathrm{d}$ of energy-allowable gain, a biological value of $0.66 \mathrm{for}$ MP (18), and the whole-body essential AA composition of lambs (1).

${ }^{\mathrm{b}}$ Metabolizable AA supplies were calculated based on duodenal and ileal flows of individual AA for lambs fed the same amount of this diet prior to this study by our group, under the same experimental conditions, with Yb-acetate and Cr-EDTA as dual markers in solid and liquid digesta, respectively (19).

c The AA profile of the mixed AA solution was determined based on the difference between the estimated AA requirements and metabolizable AA supply. Histidine was not added, because its estimated supply was beyond its predicted requirement. The solutions for the mixed AA duodenal infusion were prepared according to the method of Nolte et al. (2008).

${ }^{d}$ The total duodenal supplies of absorbable methionine were designed at 55\%, 70\%, 85\%, 100\%, 115\%, 130\%, 145\%, 160\% and $175 \%$ of the predicted requirement (1.65 g/day). The graded amounts of L-methionine in the series of mixed amino acid solutions equal to the total supplies minus the net absorptions of Met in small intestine (0.74 g/day), i.e., 0.17, 0.41, 0.66, 0.91, 1.16, 1.40, 1.65, 1.90 and $2.15 \mathrm{~g}$ per lamb per day.

nutrient levels of the diet are listed in Table 1. The daily dry matter intake (DMI) was restricted to $1100 \mathrm{~g}$ (approx. $1.7 \times$ maintenance) to ensure that no refusals were left. Lambs had free access to fresh water and a mineralized and vitaminized salt block to prevent any deficiency of mineral elements or vitamins. Lambs were adapted to the diet for $30 \mathrm{~d}$ before the initiation of treatments.

The feed samples were analyzed for moisture, crude ash and Kjeldahl nitrogen (N) according to AOAC (2012) standard procedures 934.01, 927.02 and 976.05, respectively. Neutral detergent fiber (NDF) and acid detergent fiber (ADF) were analyzed using the method of Van Soest et al. (1991) without sodium sulfite. Heat-stable $\alpha$-amylase (A3306; Sigma Chemical Co., St. Louis, MO, USA) was included in the NDF procedure $(10 \mu \mathrm{L}$ per $0.50 \mathrm{~g}$ of sample). The amino acid content of the feed was determined by an amino acid auto-analyzer (Hitachi L8900, Tokyo, Japan) according to the method of AOAC (2000). Acid hydrolysis (to determine all amino acids except methionine, cystine and tryptophan) and acid hydrolysis with performic oxidation (to determine methionine and cystine) were conducted.

\subsection{Design and treatments}

Duodenal infusions of mixed AA were employed during the main study to evaluate IAAO rate measurements as a means of determining Met requirements of growing lambs. To make Met first limiting, a mixture of AA (45.83 g/d totally) devoid of Met was infused duodenally. Methionine was added to this mixture in graded amounts for the various infusion treatments to make the total Met supplies accounted for 55\%, 70\%, 85\%, 100\%, 115\%, 130\%, 145\%, 160\% and 175\% of the predicted requirement (1.64 $\mathrm{g}$ metabolizable Met per day). The IAAO study was repeatedly conducted on the last day after a 6-d duodenal infusion of a mixed AA solution $(500 \mathrm{~mL} / \mathrm{d})$ with one of 9 graded amounts of Met. Each level of Met was tested weekly, starting with the lowest infusion rate first $(0.17 \mathrm{~g} / \mathrm{d}$, Table 2$)$. A 6-d adaptation period was considered sufficient, because ruminants rapidly adapt to postruminal infusions of nutrients (Hovell et al., 1983; Moloney et al., 1998).

The AA profile of the mixed AA solution was determined based on the difference between predicted AA requirements and the metabolizable AA supply. The metabolizable AA requirements were calculated using net protein requirements (factorial equation of NRC, 1985) for $200 \mathrm{~g}$ /d of energy-allowable gain, a biological value of 0.66 for MP (NRC, 1985), and the whole-body essential AA composition of lambs (Liu and Masters, 2003). The metabolizable supply was based on duodenal and ileal flows of individual AAs for lambs fed the same diet prior to this study under the same experimental conditions (average 0.74 g/day, Niu et al., 2016). The solutions for the mixed AA duodenal infusion (Table 2) were prepared according to the method of Nolte and Ferreira (2004).

\subsection{Tracer infusion and breath collection}

L-[1- $\left.{ }^{13} \mathrm{C}\right]$ Phenylalanine (99\% ATP, Cambridge Isotopes Laboratories, Woburn, MA) was adopted as the indicator amino acid to 


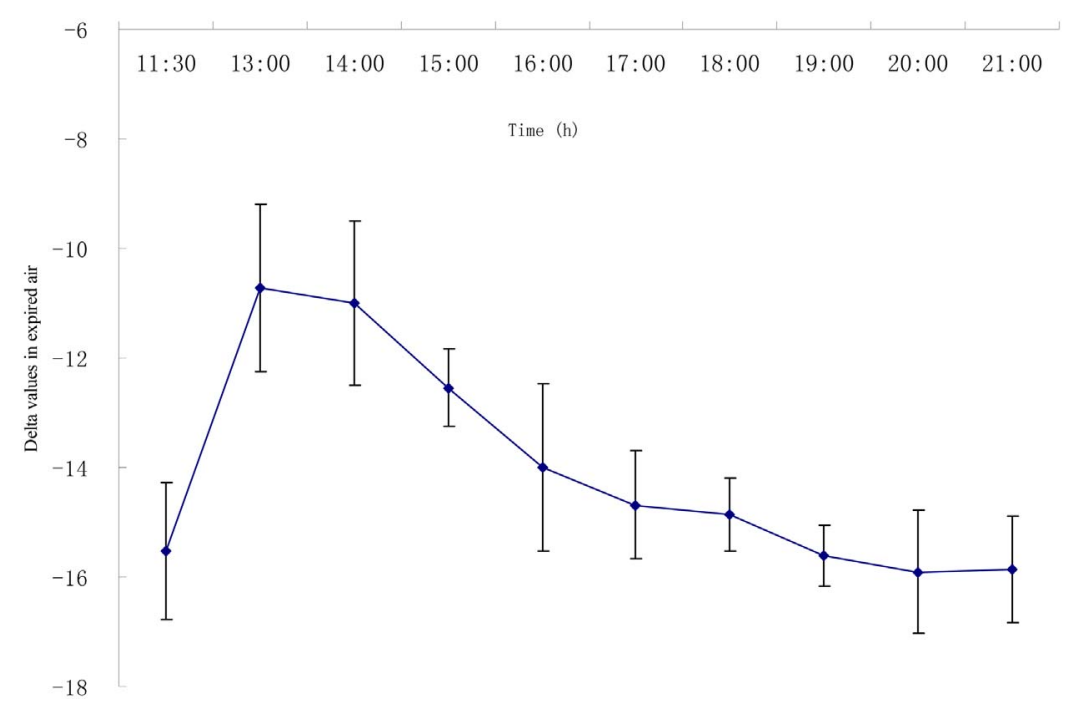

Fig. 1. Course of breath ${ }^{13} \mathrm{CO}_{2}$ enrichments before and after a single bolus of ${ }^{13} \mathrm{C}$-phenylalanine $(5.32 \mathrm{mg} / \mathrm{kg} \mathrm{BW})$ injected intravenously at $12: 00 \mathrm{~h}$.

conduct the IAAO tests in these studies. The stock solution of $\mathrm{L}-\left[1-{ }^{13} \mathrm{C}\right]$ phenylalanine $(20 \mathrm{~g} / \mathrm{L})$ was prepared with sterile water by passage through a $0.22-\mu \mathrm{m}$ filter (Carriglwohill, Ireland) under a laminar flow hood and then dispensed into multiple dose vials and stored at $4{ }^{\circ} \mathrm{C}$ until use.

Thirty minutes before commencing the isotope infusion (11:30), breath air samples for all of the lambs were collected to determine the natural background enrichment of ${ }^{13} \mathrm{C}$ isotope. To determine the dynamic metabolic trend of ${ }^{13} \mathrm{C}$-Phe in the body and to test whether or not an infusion dosage was appropriate for the IAAO study, all of the lambs were subjected to a single injection of ${ }^{13} \mathrm{C}$-Phe $(5.32 \mathrm{mg} / \mathrm{kg} \mathrm{BW}$ ) via jugular vein at 12:00 (time 0 ), which was $4 \mathrm{~h}$ after the morning feeding. Breath collection started $60 \mathrm{~min}$ later using a respiratory facemask connected to an air-bag with an interval of $60 \mathrm{~min}$. A total of nine expired air samples were collected for each lamb from $60 \mathrm{~min}$ to $540 \mathrm{~min}$ after starting the infusion.

Based on the results of preliminary pilot studies, all of the lambs were repeatedly subjected to primed, constant 4-h infusions to test whether or not this protocol could produce an isotopic steady state in expired $\mathrm{CO}_{2}$. Each lamb received a priming dose of $0.67 \mathrm{mg} / \mathrm{kg}$ BW of ${ }^{13} \mathrm{C}$-Phe, together with $0.18 \mathrm{mg} / \mathrm{kg}$ BW of ${ }^{13} \mathrm{C}$-sodium bicarbonate (99\% ATP, Cambridge Isotopes Laboratories, Woburn, MA) at time 0 (12:00). The priming dose was manually injected via the jugular vein. Immediately thereafter, the constant infusion $(1.33 \mathrm{mg} / \mathrm{h} \mathrm{kg} \mathrm{BW})$ was started using variable speed syringe pumps with sterile saline to carry ${ }^{13} \mathrm{C}$-Phe. Once the isotope infusion started, breath collections occurred at 90, 120, 150, 180 and $210 \mathrm{~min}$. As indicated in Fig. 2, this infusion procedure produced a steady state of ${ }^{13} \mathrm{CO}_{2}$ in an expired air within $2 \mathrm{~h}$. On account of this, all of the breath collections were fixed at 90 , 150, and $210 \mathrm{~min}$ for the following IAAO studies.

Immediately after finishing the collections of exhaled air samples, the bag was connected to an infrared monitor (GXH-3010E, Hua Yun, Beijing) to measure the percentage of $\mathrm{CO}_{2}$ in the samples. Then, a vacuum pump connected to an airflow meter was used to determine the total sample volumes. The barometric pressure and room temperature were recorded to obtain volumes at standard temperature and pressure.

\subsection{Calculations and statistical analysis}

The expired ${ }^{13} \mathrm{CO}_{2}$ enrichment was measured using a continuous flow isotope ratio mass spectrometer (Isoprime100, UK) and was expressed as atom percent excess against a reference standard of compressed $\mathrm{CO}_{2}$ gas. A plateau of ${ }^{13} \mathrm{CO}_{2}$ in breath air was defined as the absence of a significant slope $(\mathrm{P}>0.1$ ), and the CV during the plateau was less than 10\% (Moehn et al., 2008). The difference between mean breath ${ }^{13} \mathrm{CO}_{2}$ enrichments of the baseline and plateau samples was used to determine the atom percent excess (APE) above the baseline in the isotopic steady state (Riazi et al., 2003).

The ${ }^{13} \mathrm{C}$ enrichment in expired air was expressed as delta $(\delta)$ :

$$
\delta=\left({ }^{13} \mathrm{C} \text { enrichment } \text { sample }-{ }^{13} \mathrm{C} \text { enrichment }{ }_{\mathrm{PDB}}\right) /{ }^{13} \mathrm{C} \text { enrichment } \mathrm{PDB}_{\mathrm{P}} \times 1000,
$$

where $\delta$ is the relative enrichment of ${ }^{13} \mathrm{C}$ in breath. PDB indicates Pee Dee Belemnite, which contains a ${ }^{13} \mathrm{C} /{ }^{12} \mathrm{C}$ of 0.0112372 .

The rate of ${ }^{13} \mathrm{CO}_{2}$ released by ${ }^{13} \mathrm{C}$-Phe oxidation $\left(\mu \mathrm{mol}{ }^{13} \mathrm{C} \mathrm{kg}^{-1} \mathrm{~h}^{-1}\right)$ is calculated based on the work of Matthews et al. (1980), with a minor modification of constant $\mathrm{R}$ (see below):

$$
\mathrm{F}^{13} \mathrm{CO}_{2}=\mathrm{FCO}_{2} \times \mathrm{ECO}_{2} \times 60 \times 41.6 /(\mathrm{W} \times 100 \times \mathrm{R})
$$

where $\mathrm{FCO}_{2}$ is the $\mathrm{CO}_{2}$ production rate $\left(\mathrm{cm}^{3} \mathrm{~min}^{-1}\right), \mathrm{ECO}_{2}$ is the ${ }^{13} \mathrm{CO}_{2}$ enrichment in expired air at isotopic steady state (atom\% excess), and $\mathrm{W}$ is the lamb's body weight (kg). The constants $60 \mathrm{~min} \mathrm{~h}^{-1}$ and $41.6 \mu \mathrm{mol} \mathrm{cm}^{-3}$ (at STP) convert FCO $\mathrm{F}_{2}$ to $\mu \mathrm{mol} \mathrm{h}^{-1}$. 


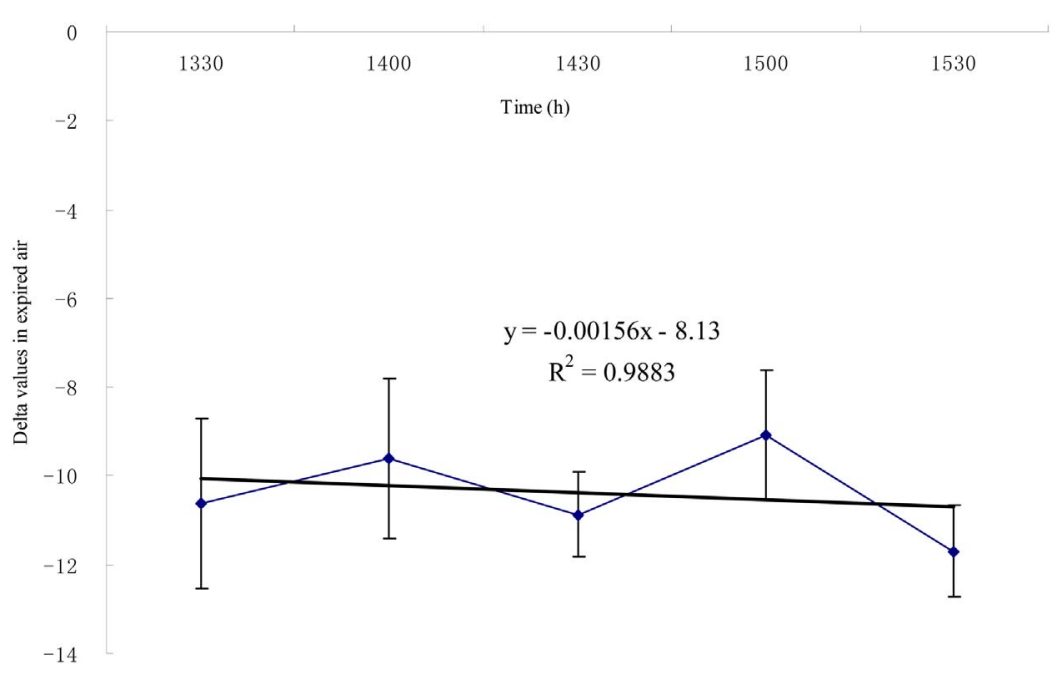

Fig. 2. Course of breath ${ }^{13} \mathrm{CO}_{2}$ enrichments after priming and 4-h of continuous intravenous infusion of ${ }^{13} \mathrm{C}$-phenylalanine started at 12 :00 h.

The factor 100 changes atom $\%$ excess from a percent to a fraction. The factor $\mathrm{R}(0.85)$ is the fraction of ${ }^{13} \mathrm{CO}_{2}$ derived from ${ }^{13} \mathrm{C}-\mathrm{Phe}$ oxidation released as breath $\mathrm{CO}_{2}$ (Lobley et al., 2003).

The oxidation rates were expressed as a percentage of the infused dose. The estimates of the mean Met requirement were derived by a breakpoint analysis of the rate of phenylalanine oxidation using the Proc Mixed procedure of SAS (2003) followed by a twophase linear regression crossover model, as described by Zello et al. (1993). The requirements for individual lambs were averaged, and a CV was calculated. The differences with $\mathrm{P}<0.10$ were considered significant, and the differences with $0.10<\mathrm{P}<0.15$ were considered to have a tendency towards significance.

\section{Results}

In the pilot study, the delta value of ${ }^{13} \mathrm{CO}_{2}$ in exhaled air rapidly increased $(\mathrm{P}<0.001)$, with a peak value at approximately 90-150 min after the single injection via the jugular vein (Fig. 1). Then, the delta value of ${ }^{13} \mathrm{CO}_{2}$ rapidly declined from 150 to $270 \mathrm{~min}$ after priming dose. No significant differences were observed between the delta value from 270 min afterwards and the baseline at $-30 \mathrm{~min}(\mathrm{P}>0.05)$. The results indicated that the dosage of ${ }^{13} \mathrm{C}$-Phe was adequate to conduct the IAAO study on lambs, but the single IV injection of ${ }^{13} \mathrm{C}$-Phe failed to maintain a relative steady state of plateau for breath collection.

Fig. 2 indicates that an isotopic steady state in expired $\mathrm{CO}_{2}$ was achieved at 90 min after the initiation of infusion and was maintained for $2 \mathrm{~h}$, since regression analysis of ${ }^{13} \mathrm{CO}_{2}$ enrichments in breath air on collection time demonstrated that there was no difference $(\mathrm{P}>0.1)$ between the slope $(-0.00156)$ and zero $\left(\mathrm{R}^{2}=0.9883\right)$. The CV during the plateau was less than $10 \%$.

The mean initial and final BW values of the lambs were $30.8 \mathrm{~kg}(\mathrm{SD}=0.40)$ and $42.5 \mathrm{~kg}(\mathrm{SD}=0.66)$, respectively. Phenylalanine oxidation was from $21.6 \%$ to $32.8 \%$ (mean of $26.8 \%$, SD $=3.4$ ) of the infused dose at steady state, depending upon the Met infusing dosage (Fig. 3). Phenylalanine oxidation was affected $(\mathrm{P}<0.001)$ by the duodenal infusing Met graded amount and was not affected by body weight $(\mathrm{P}=0.25)$ or airflow rate $(\mathrm{P}=0.23)$. The indicator AA oxidation (\% of dose infused) decreased linearly and in a dose-dependent fashion up to the 7th level of Met dosage $(1.65, \mathrm{P}<0.05)$, and it was not different among the 3 highest amounts of Met infusion (1.65-2.15, $\mathrm{P}>0.05)$. The breaking point of the average indicator oxidation rate for all of the lambs was estimated to be $1.28 \pm 0.11 \mathrm{~g} /$ day of supplemental Met. The 95\% confidence interval for the mean Met requirement was 1.07 (lower CI) and 1.48 (upper CI) Met (Fig. 3). The average net absorbance of Met at the small intestine was $0.74 \pm 0.14 \mathrm{~g} / \mathrm{day}$ for lambs with similar live weights that were fed the same amount of this diet and determined by our group prior to this study. Thus, the total postruminal minimum requirement of Met would be $2.02 \mathrm{~g} / \mathrm{day}$. The individual postruminal minimum requirements of all 3 lambs varied from $1.93 \mathrm{~g} /$ day to $2.14 \mathrm{~g}$ /day, with an SD of 0.11 or $5.0 \%$ of the mean requirement.

\section{Discussion}

The objective of the current experiment was to identify whether or not Met could limit the N retention of growing lambs and to determine the minimum Met requirement in growing lambs that weighed, on average, $36 \mathrm{~kg}$ during the study period. By supplying lambs with consecutive infusing treatments duodenally, the Met requirement and the associated variability for each individual lamb were estimated by using the IAAO technique within $9 \mathrm{wk}$. Methionine was chosen to estimate its requirement in the current experiment because it was predicted to be the most limiting AA based on our assessment of metabolizable AA supplies and requirements (see above) and because many studies (Nimrick et al., 1970; Storm and Ørskov, 1984; Nolte and Ferreira, 2004; Nolte et al., 2008) reported that Met was limiting for growing sheep when microbial protein was the predominant source of absorbable AA. In addition to its direct role in protein accretion, Met may be transsulfurated to Cys for support of wool production (Storm and 


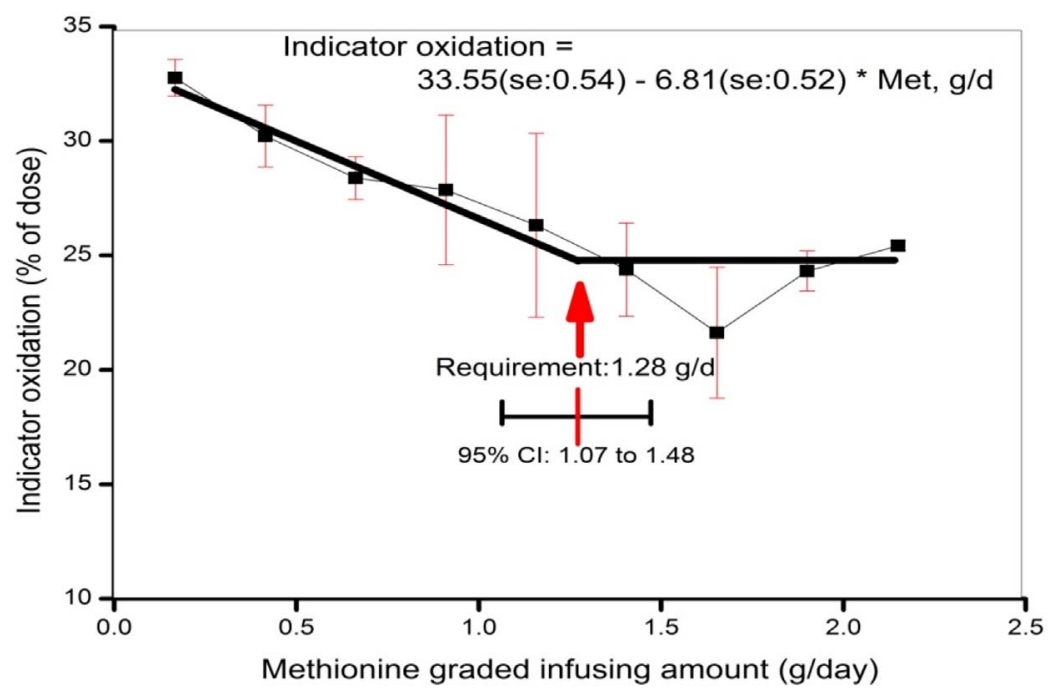

Fig. 3. Indicator AA oxidation response to increasing dietary L-Met concentration. Breakpoint (requirement) was determined using a 2-phase linear regression model. $\mathrm{CI}=$ confidence interval

Ørskov, 1984), and it may also be necessary for functions, such as the synthesis of polyamines (Nolte and Ferreira, 2004) and methylation of phospholipids proteins, nucleic acids, and other molecules (MacRae et al., 1993; Hynd and Nancarrow, 1996).

There are two major difficulties in determining the Met requirement for humans and animals by using the traditional factorial method. The first is the knowledge regarding the amino acid composition of endogenous N, which is not yet understood (Liu and Masters, 2000). Although it is usually assumed to be the average amino acid composition of the whole body, the reliability of this assumption has not been experimentally confirmed. The second problem is the interconversion of some amino acids and synthesis de novo, making the quantification of the efficiency of amino acid utilization very complex. For example, the high efficiency of Cys was calculated from Cys retention and absorption. The amount of Cys converted from Met was not included in the efficiency calculation, so the efficiency was overestimated (Liu and Masters, 2003).

Because of the problems described above, a new approach for the measurement of amino acid requirements for human beings and pigs was developed (Moehn et al., 2008; Elango et al., 2008). In this system, the oxidation of the indicator amino acid in response to varying levels of total sulfur amino acids intake was indirectly measured using IAAO techniques, and the requirement was defined from the minimum intake to balance the daily rate of the irreversible oxidation of the amino acid (Finkelstein, 1990; Lobley, 1992; Moehn et al., 2008). Using this system, the requirements of Met (with no Cys) for adult humans was determined by the IAAO and 24-h IAAO/IAAB method were $12.6 \mathrm{mg} / \mathrm{kg} /$ day and $15 \mathrm{mg} / \mathrm{kg}$ /day, respectively (Di Buono et al., 2001; Elango et al., 2008). Using a similar IAAO technique (Moehn et al., 2008), the mean Met requirement for individual pigs was determined to be $0.34 \%$ of the diet, which was similar to the recommended dietary Met concentration of $0.325 \%$ for pigs of this BW and feed intake by NRC (1998).

To determine the minimum or obligatory Met requirement using the IAAO technique, Cys (or the dimer of Cys, cystine) must be provided at sufficient levels to meet at least its own requirement for pigs or humans (NRC, 1998; Kurpad et al., 2003). However, in cattle, supplemental cysteine did not effectively spare methionine (Chung and Baker, 1992). Additionally, studies with a similar model (Campbell et al., 1997; Ball et al., 2006) did not observe any sparing of methionine by betaine or choline, which were methyl group sources. These results suggested that the methionine requirement should be considered independent of the cysteine supply. In sheep, cystine accounts for approximately 10\% (8.6-13.1\%) of the amino acids in wool protein (Löest, 1999) compared with 1.3\% in the whole body (Löest et al., 2002). The concentration of Met in wool was low, approximately half of the concentration in the whole body. Thus, the additional Cys in the duodenal infusion solutions (supplied as L-Cys_HCl) was supplied to meet its predicted requirement in the current experiment. Therefore, the results represented the minimum Met requirement.

In the current experiment, we tried to investigate the minimum requirement of metabolizable Met using the IAAO technique, and tentatively estimated a value of $2.02 \mathrm{~g}$ /day with a CV of $9.0 \%$ among lambs (Fig. 3). However, its accuracy must be affected by some factors or difficulties. Firstly, the expensive cost of IAAO test with ${ }^{13} \mathrm{C}$-Phe being the indicator amino acid has greatly limited the number of lambs to only three for each infusing level of Met. The experimental design did have confounding effect between infusing level of Met and week. On account of this, lambs with an initial body weight of $30 \mathrm{~kg}$ at about 4-5 month of age were chosen to conduct IAAO test, and the adaptation period for each infusing level was shorten to 6 days. Whole-body protein synthesis in lambs expressed on a metabolic liveweight basis increases during the first days following birth, declines very rapidly within 6 months, and thereafter remains stable with increasing age (Attaix et al., 2005). If the steady state of urea pool in lambs for changing level of infusion could be established within a few days like monogastric animals (Moehn et al., 2004), then sufficient levels of AA intake can be tested within short experiment durations without changing their physiological state. Secondly, the duodenal supply of ruminal microbial protein was influenced by dietary energy intake, in order to maintain a relatively constant duodenal flow of ruminal microbial protein, all the lambs were restricted to fed at a fixed level of DMI, i.e. $1.7 \times$ maintenance level. Unfortunately, this 
procedure might bring about the inadequate supply of energy to be utilized for protein accretion in lambs. It has been well documented that the whole body or muscle protein synthesis increases with metabolzable energy intake in sheep fed above maintenance level (Attaix et al., 2005). So, additional energy sources such as glucose might be provided via the duodenal infusing solution to overcome this problem. Finally, wool production represents an irreversible loss of amino acids that might otherwise be used for tissue deposition. Additionally, wool contains a high concentration of Cys, and its production requires a large amount of SAA, either as Cys directly or as Met for the synthesis of Cys (Titgemeyer, 2003). Due to the lack of data on the conversion of $\mathrm{N}$ loss to amino acid loss, and on the utilization efficiencies of individual amino acids for various productive purposes, the requirements of SAA for wool production have not been well quantified (Liu and Masters, 2000). The estimated requirements for Met and Cys absorption for Merino sheep at maintenance are $0.45 \mathrm{~g}$ /day to $0.75 \mathrm{~g}$ /day and $0.52 \mathrm{~g} /$ day to $0.63 \mathrm{~g} / \mathrm{day}$, respectively, depending on the live weight of the sheep. When the wool growth rate increased to $10 \mathrm{~g} / \mathrm{day}$, the requirements for Met and Cys increased to 0.91 to $1.24 \mathrm{~g} /$ day and 1.97 to $2.02 \mathrm{~g} /$ day, respectively. The requirements were presented as the Met and Cys absorbed into the circulation system, and the ratio of portal drained viscera (PDV) to mesenteric drained viscera (MDV) flux for Met was 0.67 (MacRae et al., 1997 ; Berthiaume et al., 2001; Lobley et al., 2003), so the metabolizable Met requirement would be 1.36-1.85 g/day, which was close to our estimated values by the IAAO method for growing lambs under the current experimental conditions.

The results of the present study seemed to support the indicator amino acid oxidation technique for determining the minimum requirement of essential amino acids in growing lambs, through the duodenal infusion of graded amounts of the amino acid of interest. By using this technique, the current experiment determined that the Met requirement in growing lambs was $2.02 \mathrm{~g} / \mathrm{day}$ under practical feeding conditions. Nevertheless, since the accuracy was affected by many factors, particularly energy intake, rate of weight gain, etc., caution should be taken to interpret and use this data. Furthermore, technical conditions of this new technique still need a careful assessment for measuring indispensable amino acids requirements for ruminant animals.

\section{Conflicts of interest}

There is no conflict of interest.

\section{Acknowledgments}

This work was financially supported by the National Science Foundation of China [31260557]; Doctors Special Fund of Xinjiang Production and Construction Corps [2013BB018]. The authors would like to thank Mrs. Li Fengming and Dr. Li Hao for their technical support for the duodenal fistula surgery. We also thank Dr. Li Yuzhong at the Environmental Stable Isotope Laboratory, CAAS, for measuring the ${ }^{13} \mathrm{C}$ isotope enrichment by continuous flow isotope ratio mass spectrometer. GW, CDF, and L-CL designed the research. GW, LC, ZF and GXM conducted the research. GW and LC analyzed the data. GW, LC, and L-CL wrote the manuscript. LCL had primary responsibility for the final content. All of the authors read and approved the final manuscript.

\section{References}

AOAC, 2000. Official Methods of Analysis. Association of Official Analytical Chemists, Arlington, VA.

AOAC, 2012. Official Methods of Analysis. Association of Official Analytical Chemists, Washington, DC.

Attaix, D., Remond, D., Savary-Auzeloux, I.C., 2005. Protein metabolism and turnover. In: Dijkstra, J., Forbes, J.M., France, J. (Eds.), Quantitative Aspects of Ruminant Digestion and Metabolism. CABI Press, Wallingford, United Kingdom, pp. 373-397.

Ball, R.O., Bayley, H.S., 1984. Tryptophan requirement of the 2.5-kg piglet determined by the oxidation of an indicator amino acid. J. Nutr. 114, 1741-1746.

Ball, R.O., Courtney-Martin, G., Pencharz, P.B., 2006. The in vivo sparing of methionine by cysteine in sulfur amino acid requirements in animal models and adult humans. J. Nutr. 136, 1682S-1693S.

Berthiaume, R., Dubreuil, P., Stevenson, M., McBride, B.W., Lapierre, H., 2001. Intestinal disappearance and mesenteric and portal appearance of amino acids in dairy cows fed ruminally protected methionine. J. Dairy Sci. 84, 194-203.

Bertolo, R.F., Moehn, S., Pencharz, P.B., Ball, R.O., 2005. Estimate of the variability of the lysine requirement of growing pigs using the indicator amino acid oxidation technique. J. Anim. Sci. 83, 2535-2542.

Bross, R., Ball, R.O., Pencharz, P.B., 1998. Development of a minimally invasive protocol for the determination of phenylalanine and lysine kinetics in humans during the fed state. J. Nutr. 128, 1913-1919.

Campbell, C.G., Titgemeyer, E.C., St-Jean, G., 1997. Sulfure amino acid utilization by growing steers. J. Anim. Sci. 75, $230-238$.

Chung, T.K., Baker, D.H., 1992. Methionine requirement of pigs between 5 and 20 kilograms body weight. J. Anim. Sci. 70, $1857-1863$.

Di Buono, M., Wykes, L.J., Ball, R.O., Pencharz, P.B., 2001. Total sulfur amino acid requirement in young men as determined by indicator amino acid oxidation L$\left[1-{ }^{13} \mathrm{C}\right]$ phenylalanine. Am. J. Clin. Nutr. 74, 761-766.

Elango, R., Ball, R.O., Pencharz, P.B., 2008. Individual amino acid requirements in humans: an update. Curr. Opin. Clin. Nutr. Metab. Care 11, 34-39.

Finkelstein, J.D., 1990. Methionine metabolism in mammals. J. Nutr. Biochem. 1, 228-237.

Gao, W., Zhang, B.W., Lv, B., Liu, C.L., Chen, D.F., 2016. Ruminal degradability and intestinal digestibility of individual amino acids in mixed diets with different crude protein levels measured by the modified in vitro three-step and mobile nylon bag technique. Anim. Sci. J. 87, 547-556.

Hovell, F.D., Ørskov, E.R., MacLeod, N.A., McDonald, I., 1983. The effect of changes in the amount of energy infused as volatile fatty acids on the nitrogen retention and creatinine excretion of lambs wholly nourished by intragastric infusion. Br. J. Nutr. 50, 331-343.

Hynd, P.I., Nancarrow, M.J., 1996. Inhibition of polyamine synthesis alters hair follicle function and fibre composition. J. Invest. Dermatol. $106,249-253$.

Kim, K.I., Bayley, H.S., 1983. Amino acid oxidation by young pigs receiving diets with varying levels of sulfur amino acids. Br. J. Nutr. 50, $383-390$.

Kurpad, A.V., Regan, M.M., Varalakshmi, S., Vasudevan, J., Gnanou, J., Raj, T., Young, V.R., 2003. Daily methionine requirements of healthy Indian men, measured by a 24-h indicator amino acid oxidation and balance technique. Am. J. Clin. Nutr. 77, 1198-1205.

Löest, C.A., Titgemeyer, E.C., St-Jean, G., Van Metre, D.C., Smith, J.S., 2002. Methionine as a methyl group donor in growing cattle. J. Anim. Sci. 80, $2197-2206$.

Löest, C.A., 1999. Methionine and Betaine for Growing and Finishing Cattle. Ph.D. Thesis. Kansas State University, Manhattan, KS.

Liu, S.M., Masters, D.G., 2000. Quantitative analysis of methionine and cysteine requirements for wool production of sheep. Anim. Sci. 71, 175-185.

Liu, S.M., Masters, D.G., 2003. Amino acid utilization for wool production. In: D’Mello, J.P.F. (Ed.), Amino Acids in Animal Nutrition. CABI Press, Wallingford, United Kingdom, pp. 309-328. 
Lobley, G.E., Shen, X.Z., Le, G.W., Bremner, D.M., Milne, E., Calder, A.G., Anderson, S.E., Dennison, N., 2003. Oxidation of essential amino acids by the ovine gastrointestinal tract. Br. J. Nutr. 89, 617-629.

Lobley, G.E., 1992. Control of the metabolic fate of amino acids in ruminants: a review. J. Anim. Sci. 70, 3264-3277.

MacRae, J.C., Walker, A., Brown, D., Lobley, G.E., 1993. Accretion of total protein and individual amino acids by organs and tissues of growing lambs and the ability of nitrogen balance techniques to quantitate protein retention. Anim. Prod. 57, 237-245.

MacRae, J.C., Bruce, L.A., Brown, D.S., Farningham, D.A.H., Franklin, M., 1997. Absorption of amino acids from the intestine and their net flux across the mesentericand portal-drained viscera of lambs. J. Anim. Sci. 75, 3307-3314.

Mata, G., Masters, D.G., Buscall, D., Street, K., Schlink, A.C., 1995. Responses in wool growth, liveweight, glutathione and amino acids: in Merino wethers fed increasing amounts of methionine protected from degradation in the rumen. Aust. J. Agr. Res. 46, 1189-1204.

Matthews, D.E., Motil, K.J., Rohrbaugh, D.K., Burke, J.F., Young, V.R., Bier, D.M., 1980. Measurement of leucine metabolism in man from a primed, continuous infusion of L-[1- $\left.{ }^{13} \mathrm{C}\right]$ leucine. Am. J. Physiol. 238, E473-E479 (Endocrinol. Metab. 1).

Moehn, S., Bertolo, R.F.P., Pencharz, P.B., Ball, R.O., 2004. Indicator amino acid oxidation responds rapidly to changes in lysine or protein intake in growing and adult pigs. J. Nutr. 134, 836-841.

Moehn, S., Shoveller, A.K., Rademacher, M., Ball, R.O., 2008. An estimate of the methionine requirement and its variability in growing pigs using the indicator amino acid oxidation technique. J. Anim. Sci. 86, 364-369.

Moloney, A.P., Beermann, D.H., Gerrard, D., Robinson, T.F., Finnerty, K.D., 1998. Temporal change in skeletal muscle IGF-I m-RNA abundance and nitrogen metabolism responses to abomasal casein infusion in steers. J. Anim. Sci. 76, 1380-1388.

NRC, 1985. Nutrient Requirements of Sheep. National Academy Press, Washington, DC

NRC, 1998. Nutrient Requirements for Swine. National Academy Press, Washington, DC.

Nimrick, K., Hatfield, E.E., Kaminski, J., Owens, F.N., 1970. Qualitative assessment of supplemental amino acid needs for growing lambs fed urea as sole nitrogen source. J. Nutr. 100, 1293-1300.

Niu, L., Yin, H., Zheng, M., Gan, M.L., Chen, A.D., Liu, C.L., Chen, D.F., Gao, W., 2016. Effects of dietary crude protein levels on the amino acid flows and absorbability in the small intestine of lamb. Chin. J. Anim. Nutr. 28, 1241-1249.

Nolte, J.E., Ferreira, A.V., 2004. The microbial protein and undegradable essential amino acid requirements for the growth of male Merino and Dohne Merino lambs. S. Afr. J. Anim. Sci. 34 (Suppl. 2), 86-88.

Nolte, J.E., Löest, C.A., Ferreira, A.V., Waggoner, J.W., Mathis, C.P., 2008. Limiting amino acids for growing lambs fed a diet low in ruminally undegradable protein. J. Anim. Sci. 86, 2627-2641.

Pencharz, P.B., Ball, R.O., 2003. Different approaches to define individual amino acid requirements. Annu. Rev. Nutr. 23, 101-116.

Reis, P.J., Tunks, D.A., Munro, S.G., 1990. Effects of the infusion of amino acids into the abomasum of sheep, with emphasis on the relative value of methionine, cysteine and homocysteine for wool growth. J. Agr. Sci. Camb. 114, 59-68.

Riazi, R., Wykes, L.J., Ball, R.O., Pencharz, P.B., 2003. The total branched-chain amino acid requirement in young healthy adult men determined by indicator amino acid oxidation by use of $\mathrm{L}_{-}\left[1_{-}{ }^{13} \mathrm{C}\right]$ phenylalanine. J. Nutr. 133, 1383-1389.

SAS Institute, 2003. SAS/STAT User's Guide. Statistics, Version 8.03. SAS Inst., Inc., Cary, NC.

Storm, E., Ørskov, E.R., 1984. The nutritive value of rumen micro-organisms in ruminants. 4 The limiting amino acids of microbial protein in growing sheep determined by a new approach. Br. J. Nutr. 52, 613-620.

Titgemeyer, E.C., 2003. Amino acid utilization in growing and finishing ruminants. In: D’Mello, J.P.F. (Ed.), Amino Acids in Animal Nutrition. CABI Press, Wallingford, United Kingdom, pp. 329-346.

Van Soest, P.J., Robertson, J.B., Lewis, B.A., 1991. Methods for dietary fiber, neutral detergent fiber, and nonstarch polysaccharides in relation to animal nutrition. J. Dairy Sci. 74, 3583-3597.

Williams, A.J., Murison, R., Padgett, J., 1988. Metabolism of sulphur-containing amino acids by pregnant Merino ewes. Aust. J. Biol. Sci. 41, 247-259.

Zello, G.A., Pencharz, P.B., Ball, R.O., 1993. Dietary lysine requirement of young adult males determined by oxidation of L-[1- $\left.{ }^{14} \mathrm{C}\right]$ phenylalanine. Am. J. Physiol. Endocrinol. Metab. 264, E677-E685. 